\title{
SUBURBAN FEAR, MEDIA AND GATED COMMUNITIES IN DURBAN, SOUTH AFRICA
}

\author{
ABSTRACT A disjuncture between the \\ reality of crime and its perception has \\ created a culture of fear within South \\ Africa that bolsters gated community \\ development and an accompanying fear \\ industry that supports media, private \\ security companies, and a number of \\ other industries that provide security \\ apparatuses. Is the establishment of \\ gated communities an irrational response \\ to perceptions of crime in South Africa \\ in the twenty-first century? Or, are they \\ deemed necessary in a perceived culture \\ of violence that exists in the country? The \\ article explores these questions through \\ ethnographic research with residents \\ of a gated community and the security \\ company hired to provide security for the
}




\section{estate reflecting on the reality and perceptions of crime in the "New" South Africa.}

KEYWORDS: gated communities, South Africa, fear, crime, ethnography

Suburbs are surrounded by conceptual and real barriers, both by their history and their continued development throughout the world. Although not initially conceived as a popular destination to escape the ills of urban areas (Jackson 1985), and taking into account their conception as undesired spaces that result from people pushed out of cities by various social forces (Rutheiser 1996, Smith 1996), residence in suburban environments is often looked upon as the end result of a path of success. ${ }^{1}$ Once one lives within the "ideal" suburb, they have supposedly overcome a number of obstacles in terms of distance, class status, and perhaps even race to conceive of this social space as place, or home, with concomitant rationalizations to support their new or continued existence there. Whereas many barriers to suburban residence have been overcome demographically if not culturally, the contemporary gated community or estate, often found within newly created or annexed suburbs throughout the world, provides visible evidence of a real suburban barrier. The gated community and the various security mechanisms that define them visually are designed to demarcate class status and prevent access to protect residents from criminals, not necessarily to define culture. Yet, the notion of security, fear of crime, capital, culture, and gated community residence are inextricably intertwined in media representations of these places, particularly in post-apartheid South Africa.

Almost fifteen years into the post-apartheid democratic transition in South Africa finds the government and citizenry of the country still grappling with a number of prominent and interrelated social issues including an escalating HIV/AIDS pandemic, rampant poverty, swelling unemployment and a perception that crime is out of control (Mistry 2004). Simultaneously, South Africa has become a hotspot of global tourism and has been celebrated internationally for its peaceful transition and sustained democracy over the past several years. Despite the goals of the government to eliminate poverty and create a non-racial society, a separation along class and racial lines has intensified in relation to residency (Nattrass 2003). A major obstacle in the plans to create an equitable society in South Africa concerns the development, construction, and availability of housing. A correlation exists between perceptions of crime and desired residence as the majority of individuals with the means to do so are rapidly relocating to suburbs outside of urban areas and purchasing homes in gated estates emblematic of "white," or 
perhaps "class" flight. Thus, these gated communities are often seen as white cultural bastions, despite the various complexions that may be present within the walls among residents, as they are all similar in terms of class access, lifestyle achievement, and the hopeful avoidance of crime.

It could be said that crime and the evasion of its consequences is the national pastime of South Africa. It is either the focus of or tangentially connected to a large portion of popular culture. ${ }^{2}$ It is a major topic at family dinner tables, an obsession in media coverage by the South African Broadcasting Corporation, covered daily in the national press, and a source of constant policy and academic speculation. A consistent debate is whether there is a disjuncture between the reality of crime and the perception that it is out of control (Altbekar 2005; Leggett 2005, Pelser 2007). If crime is not rising but perhaps even actually decreasing (Newham 2008), then the question must be asked if a "culture of fear" (Glassner 1999), and the various industries that serve it, bolsters the increasing perception that crime is a problem and, in turn, serves as a mechanism for gated community residence and development in the country. In other words, is the media fueling gated community development in the country and therefore exacerbating a divide between the rich and the poor?

\section{GATED COMMUNITIES IN SOUTH AFRICA}

The increasing trend in gated community development in South Africa reflects the growing development of these social spaces throughout the world (Low 2005). While arguments are made that the secured enclave has existed since medieval times (Robinson 2005), or that it has been an intrinsic part of fortified spaces in urban areas (Davis 1990), the contemporary gated community found in suburban environments as part of a lifestyle development was initiated in the United States and has spread throughout the world as developers and home buyers have realized their financial potential. These fortified suburban enclaves are inhabited predominantly by the upper class and surrounded by a number of security apparatuses including boom gates, high walls, razor wire, electric fences, ever-present guards and are connected with armed response security companies (Blakely and Snyder 1997; Caldeira 1996; Low 1997, 2003a, b; Marcuse 1997). While many of these security devices exist around homes throughout the city and suburbs, especially in South Africa, there is an analytical difference between the fortified home as opposed to the fortified community. Almost every home in South Africa is fortified with a variety of layered devices including walls, razor wire, bars, locks, electronic alarm systems wired into independent armed security companies, and the presence of an attack dog if the resident is fond of pets. The post-apartheid construction of gated communities consists of 
homes that were built as part of a planned development where security apparatuses may exist in the independent home but the main source of security comes from enclosure behind a wall and/ or fence that surrounds the development with limited points of controlled access entry.

Although similar to other gated community developments globally, the conditions that surround their existence in South Africa are quite unique. These conditions are based upon a number of factors including racial identity, geography, history, culture, national legislation, and local governance just to name a few. Recent research in South Africa explores black or colored communities that exist outside of secured communities (Lemanski 2005), exploring the relation between road closures, transportation and culture, (Czegledy 2004) the role of privatization and urban identity (Dirsuweit and Wafer 2005), and the relationship of race, space, and place in gated community culture (Durington 2006). Richard Ballard has discussed gated communities as a destination for white South Africans who "semigrate" within South Africa, rather than emigrate from the country (Ballard 2004). While Bremner (2004) has related anxiety levels to Johannesburg road enclosure efforts and Jürgens et al. (2003) relates gated communities in Johannesburg to a new form of racial and class segregation in post-apartheid South Africa. Each major city in South Africa has a particular geography that determines the type of gated community development that occurs as well. Spatially, Johannesburg possesses the highest concentration of road enclosures (Landman 2002) and gated communities as the metropolis continues to sprawl closer to Tshwane. Geographically, Cape Town is ocean- and mountainsbound, and metropolitan Durban, bound by the Indian Ocean to the east, continues to expand further north into empty sugar fields.

The social and cultural spaces within each city are bounded by unique histories and are constantly being redefined in the political landscape of post-apartheid South Africa as streets and buildings are symbolically renamed to reflect a more robust and ethical history. Each major city in South Africa has a unique ethnic and racial demographic which influences gated community development and settlement. While Johannesburg has witnessed large black middleclass growth in the post-apartheid era and continues to possess the largest black majority in the country, Cape Town possesses the largest white minority in the country. Durban, as home to both Zulu and Indian South Africans, possesses a unique mix of heritage. While each city possesses gated community developments, Durban has one of the only gated communities predominantly populated by Indians (Taleb 2005) and accoutrements of Zulu heritage are found in the various names of developments throughout KwaZulu-Natal. Differences also exist in terms of ethnic, traditional, and linguistic traits among the people of each city that are often glossed over in 
policy and planning discussions on a national level (Lemanski et al. 2008). Essentially, what may work in Johannesburg may not work in Durban.

Freund and Padayachee (2002) describe the period in the 1980s toward the end of apartheid in Durban as the recognition of the informal economy and impending changes signaled a move for most businesses occupying the central business district of the city to move toward the northern suburbs. This shift in amenities, residences, and businesses started to transform the northern suburbs of Durban as malls and office parks began to develop in older beach communities followed by a proliferation of gated estate development. A large portion of these gated estate developments were created by a subsidiary of the sugar magnate Tongaat-Hulett. This subsidiary, ironically entitled Moreland, was able to transform the landscape as it saw fit since it owned large swaths of the countryside. This redevelopment of the landscape also served as social engineering due to the class access needed to occupy these new gated estates being developed north of the city. As these communities have been occupied over the last several years the inertia of this initial movement has been followed by the planned relocation of the airport that serves Durban and the latest monument to kitsch culture in the form of Shaka Zulu Casino. While the casinos and shopping malls may have open access by definition, the ability to gamble or spend excess income creates a social barrier often compounded by the historical legacy of racial injustice.

While different in many regards, all cities in South Africa have made some attempt to regulate gated community development. While this may be done on a pragmatic local level, national debates on gated communities are often framed in terms of social justice. This is particularly important due to the fact that in the apartheid era access and mobility were strictly governed and it is now a constitutional mandate in the "New" South Africa that citizens are unencumbered by these historical limitations. Thus, in no other country in the world would road enclosures or gated community development be elevated to the possibility of a human rights violation as a recent report from the South African Human Rights Commission details. ${ }^{3}$ Even with these debates, gated community development continues because it retains citizens in the country who might otherwise emigrate to avoid crime. Simultaneously, gated community developments also provide financial opportunities for a variety of individuals and industries through investment.

The main focus of much of the research on gated communities and private enclosures in South Africa and elsewhere tends to focus on the institutional and structural development of these social spaces-essentially, looking from the outside in to these communities investigating their history, creation, patterns, marketing, and 
place among other structures within city environments. It is widely agreed upon that gated communities are contested and symbolic social spaces. Throughout the world, and particularly in South Africa, they are markers of class status and affluence. For those that live outside of gated communities they are emblematic of economic disparities and serve as a hard barrier between the haves and have-nots within a society. For gated community residents, these places are safe havens from crime and other social ills affecting the world outside the walls of the estate. For these residents, their development and continued existence must be fought for in terms of protection and investment. In turn, their construction and defense also supports the growth of a fear industry made up of armed security companies and other entities that create and maintain security apparatuses supporting a general "culture of fear" (Glassner 1999).

\section{CRIME AND THE CULTURE OF FEAR IN GATED SOUTH AFRICA}

One of the major rationalizations utilized by residents of gated communities to justify their residence in secured enclaves is based upon a perception that crime throughout South Africa is out of control. The fear of crime is not a fear of petty crime so much as a fear of violent and sensational crime. The type of crime that is easily portrayed in the media such as violent abductions, bloody murders and the like that are initiated from home invasions, car hijackings or theft. In the context of the United States, Barry Glassner has discussed the development of a "culture of fear" that is dependent predominantly upon media coverage of crime and other social ills with reporting of crime far outweighing the actual statistics (Glassner 1999). One of the reasons offered by Glassner for the perpetuation of this phenomenon is that there is a large industry that benefits from the perception that crime is rampant. In addition, fear often speaks to deeper cultural issues. As he states, "The success of a scare not only depends on how well it is expressed but also ... on how well it expresses deeper cultural anxieties" (Glassner 1999: 208).

The culture of fear in South Africa is fed by media coverage that enforces a sentiment among all citizens of the country that crime touches everyone. The belief is that if one is not perpetuating crime, or has not been a victim of it directly, people might eventually resort to it out of necessity or psychosis, and therefore individuals must constantly be on guard to possibly prevent its occurrence. As Leggett states:

There is a reason for concern. South Africa does have a remarkable crime problem. A country of some 44 million, it experiences at least 22,000 murders a year, which is about 25 percent more than the United States, a violent country with 
over six and a half times the population. While the number of South Africans murdered each year is much less today than it was at the time of the democratic transition, it is still far more than could be considered "normal" by international standards (Leggett 2005: 148).

Whether or not the culture of fear in South Africa correlates with real crime statistics is a subject of debate. This is partly due to the fact that the country is finding it's footing as a new democracy and the rearrangement of social space and other cultural patterns is consistently in flux, despite the overwhelming "miracle" of democratic transition (Sparks 2003). The prominent reason for the disjuncture between the actuality of crime and its perception rests upon the fact that there are no reliable statistics for crime reporting. The South African Police Services and the national government have released crime statistics inconsistently at different times in the past fourteen years. The government actually placed a moratorium on the release of crime statistics in 2000 in order to recalibrate its figures and then lifted it in 2001 with local statistics being kept secret (Leggett 2005). Thus, any rationalization or policy based upon the reporting of crime figures is contested at best. This has fueled speculation of corruption and become an impetus for the further establishment of secured environments and the increasing growth of an associated fear industry within the country and elsewhere in places such as Brazil (Landman and Schonteich 2002).

This lack of trust of crime statistics is also accompanied by a lack of confidence in the police service. Essentially, there is a general perception in South Africa that the police are not effective in preventing crime and that they are reactive rather than proactive. This is also confirmed the actual naming of the South African Police Services in its post-apartheid manifestation. The result of this perception is an investment, both emotional and capital, into private security companies that outnumber police throughout the country and into development that will do the job that the police supposedly cannot do. The police are placed in a conundrum where the public demands the reduction of crime statistics but is unsure of the way that they or the police should respond to this need. The gap produced by the lack or inability of the police to function the way the public demands is filled by the security companies and the visible deterrents of crime in the built environment such as gated communities. The man in the uniform at the boom gate, checking license plates, calling ahead to the residence or patrolling the perimeter and interior in the emblazoned patrol vehicle, all-terrain vehicle (ATV) or bicycle fills the conceptual gap that reduces anxiety for the populous and specifically for gated community residents.

Yet, the real question of ethnographic interest is that even if crime has decreased, or the police do their job, does it really matter 
if the perception of crime has escalated due to the newness of the post-apartheid government and its perceived instability? The media and gated community developers actually have a stake in an increasing perception of out-of-control crime in order to support the burgeoning fear industry that directly benefits them in terms of advertising dollars and real estate purchases respectively. Sensational headlines describing crime narratives fuel newspaper sales and drive home purchases in secured estates. The paranoia that surrounds crime has also driven the creation of websites and has become a major concern for the tourist industry in South Africa as the country prepares to host the FIFA World Cup in 2010. These websites have been created to provide narratives of "real crime" in South Africa that the creators of these websites believe is being ignored by the government. ${ }^{4} \mathrm{~A}$ concern has risen that the revelation of sensationalist narratives of crime will actually deter tourism and World Cup attendance in 2010 so much so that there have been rumblings that FIFA may pull the World Cup competition from the country.

While the material manifestations of fear are visibly inscribed in the built environment, the culture of fear that exists throughout the country is perhaps easy to diagnose but not as easily understood or described. Ethnographic research following this trajectory has sought to explore the perspectives of both the individuals who are dependent upon security companies for their protection in gated estates, and individuals from the security companies themselves who are mutually responsible for both the psychological alleviation of residents fear and the removal of the threat of crime, while somewhat paradoxically being dependent upon the continued existence of both.

\section{SECURITY IN "SPRINGFIELD HILLS"5}

Springfield Hills is one of several planned community developments in the fastest growing part of Metropolitan Durban north of the city. The estate was one of the first successful gated estates in South Africa and has been looked upon as a model for gated community development in Johannesburg and other parts of the country both in terms of its planning and its security mechanisms. Consistently in interviews and conversations with individuals in and outside of the community throughout Durban, the estate was discussed as one of the most desired residential developments in the area. Springfield Hills is made up of over one thousand homes with plans to expand further in the next several years. Residents must conform to aesthetic restrictions in terms of home construction and lifestyle restrictions in the form of a contract signed by each family upon purchasing a home, condominium or even renting within the community. 
For instance, the Springfield Hills "Manual for Residents" is over thirty pages long and serves as a contract between new residents and estate management. The guidelines include restrictions that cover everything from restrictions on helicopter landings to general conduct. One interesting restriction covers "slaughtering," "curing of meat," and "excessive gatherings" on the estate. While this does not have far-reaching effect or argument among most new residents, it essentially limits Zulu residents who often slaughter animals for different ceremonies and large gatherings. There is a racial fear associated with slaughtering as discussed by Richard Ballard (2005). This has implications not only for who can live within gated communities in Durban, but what lifestyle choices may actually serve as symbolic and literal barriers to residency.

Principal ethnographic research was conducted throughout 2003 and for periods in 2005, 2006, and 2007 to apprehend the cultural reasoning and lifestyles of gated community residents. Research was centered on the different rationalizations that individuals work with to justify their surroundings (Durington 2006). Some see the movement to gated communities as an investment opportunity with many residents living in one property but owning one or two more in the estate which are leased out to temporary residents or vacationers. Others look at the gated community development as a retirement destination with lifestyle amenities such as golf and a sense of community that is now lost in the general population. And, as articulated principally by gated community residents in Springfield Hills, reasons for moving there are overwhelmingly justified through perceptions of crime and the need to escape other parts of the city that are no longer perceived to be safe.

In this sense, there is a constant anxiety about the possibility of what crimes could happen in the outside world that are now supposedly deterred by their new surroundings. In particular, among gated community residents, the occurrence of crime in contemporary South Africa is lamented in comparison with a past time when it was not such a major concern, as an interview excerpt with one female resident of Springfield Hills details:

Matthew: So, do you think that crime has increased a lot recently?

Charlize: I would say in the last 10 or 15 years ... when I was a child I used to walk around all the time to the mall and there were no problems. I would never, never let my kids walk around the streets now. I just ... you know, you forget about the crime and then the next day you hear a story and not just about what happened to a friend of a friend but something happens to someone you actually know either on the way to work someone smashes through their window or whatever. So the crime is an 
issue but I haven't spoken about it in a year or so ... since I moved into this estate I haven't had to talk about crime. I see it on the news and that is all.

Matthew: So crime was something that was part of your life before but now it is not?

Charlize: Yes, that is all I used to think about and talk about was crime. When I would get home I would be terrified to go in alone ... I was terrified ... and it was really controlling my life.

Matthew: So it seems like, psychologically, you are doing a lot better since moving onto the estate?

Charlize: Yes, except for the fear of hijacking. I have had a few friends that have been hijacked and it has been terrible. One of the secretaries at my work, her maid's son was involved in a hijacking syndicate and he can't get out of it or won't and they are told to follow cars around until you park and when you park somewhere they hijack you. If you are at a mall or something you are OK because they will just take your car but if you are going home they will hijack it and possibly you ... it is not just a story on Carte Blanche ${ }^{6}$ or whatever.

Matthew: You see stuff on the news but I suppose when you know someone it is different. Have you experienced crime first-hand?

Charlize: Yes, in Kloof they tried to get into our house and they are at the door trying to get in and I am on the phone with the security company and my husband broke my tennis racket, which I still won't forgive him for, banging it on the wall trying to scare them away and he wouldn't run away and our Labrador, if you can believe this, was trying to get the guy to throw him the ball and play catch or something ... seriously, can you believe it? I should have gotten a Rottweiler.

Despite the choice of which animal would be a better deterrent to crime, a number of issues arise from the interview excerpt with Charlize. Perhaps most importantly that she was on the phone with the security company rather than the police when crime was occurring. Even though she has, by her own admission, not "thought about crime" since she left her former residence in an urban neighborhood of Durban called Kloof, there is a fear of what could happen in the world outside of the gated community in which she now lives. Apparently, the consistent reporting of crime in the media primarily drives this fear, as well as stories she hears from friends and her own past experiences with being threatened or a victim of crime. The concern with crime and victimization gives rise to the fear industry in the form of personal bodyguards, anti-hijacking 
devices for automobiles, and guidelines for how to avoid being a crime victim through design (Kruger et al. 2001). Perhaps one of the most pronounced fears among gated community residents concerns the hijacking of one's vehicle once they leave the gated estate. This fear has supported one of the fastest growing parts of the fear industry, which is the recovery of stolen vehicles through tracking mechanisms sold and installed in vehicles. The commercials and advertisements for these companies are paramilitary in nature, showing armed and uniformed individuals in a variety of vehicles and helicopters finding automobiles in random locations and apprehending the suspects themselves. Perhaps the most prominent of these companies in South Africa, at least in terms of advertisement, is "Netstar," whose banner on their website proclaims "Get Your Bakkie (Truck) Back" with photos of smiling enforcers with automatic weapons (Netstar 2008).

The fear of being hijacked from one's vehicle has also produced a culture of avoidance among individuals who informally share with each other places where one should not drive that may be in close proximity to an informal settlement or a place where hijacking has occurred. This avoidance and fear is then bolstered by actual traffic signs at various stops that warn drivers that it is a "hot spot" for hijacking or "smash and grab" crime that occurs when someone smashes a window and takes property from the car or accosts the driver. And, consequently, manuals and literature that are meant to educate individuals on "how to avoid hijacking" or what to do if one is hijacked have become popular publications. One company following this trend is the "National Hi Jack Prevention Academy" that offers a variety of courses and manuals on how to prevent its occurrence (National Hi Jack Prevention Academy 2008).

Whereas all these specialized industries are flourishing in South Africa due to the rise of crime, they pale in comparison to the amount of money to be made in property development to provide residences for those whose perception of crime has convinced them to relocate. Further excerpts from the interview with Charlize, whose husband coincidentally is also a property developer, reveals this as well:

Charlize: Look crime here creates investment opportunities ... my husband and I are doing quite well because he develops homes only in gated communities and there is a huge demand for it ... and everyone is talking about the property bubble bursting but that is not going to happen for the next few developments because they have been given the go ahead and whatever...

I think if anyone is going to move anywhere or buy anywhere in South Africa that is where they are going to do it ... it would be silly not to ... you get a lovely lifestyle 
and security ... the only people that think that people who live in gated communities are snobs or whatever are people who can't or won't live in gated communities ... they should try it, you know, why don't they go rent in a gated community first and see what the story is ... there is a sense of relief that comes from knowing you don't have to worry about crime.

It is the perception of crime that drives the fear industry in South Africa both in terms of gated community development and security. The latter is one of the most profitable and expanding markets in the country with an estimated annual revenue between R10 billion and R18 billion, with 4,500 companies and over half a million security guards (BBC News 2004). As one security entrepreneur told a $\mathrm{BBC}$ reporter, "Wherever there is a criminal opportunity, there is another in protection" (BBC News 2004). While there are standard procedures at the entrance to any gated estate, varying from clearance by a guard to signing documentation, each development embellishes these procedures dependent upon local conditions and expanding technology. All of the devices contribute to a sense of safety that Charlize alludes to.

There is also a sense from the security company that is responsible for Springfield Hills that they have succeeded in preventing crime from entering the community. Yet, this is still not enough according to George, an integral member of the company responsible for the Springfield Hills security force. As he stated, there has been a recent concern with the domestics and employees of homeowners within the community itself that provides evidence for a culture of fear even if a causal mechanism is not present. As I walk around the interior of the estate with George a small bus full of black domestics who work for white homeowners rumbles by and stops at a corner to take on more passengers. As none disembark he discusses the relationship between domestics and fear of crime within the gated community,

George: Do you want to know why we have all of the buses that run around the estate and to the gates carting the gardeners, laborers, and domestics? Partly, it is because of the long distances that individuals have to walk to get to the gate they are allowed to leave from. Secondly, it is because they don't want the people ... the usual suspects, meaning young black males ... walking around when wives are home alone or when daughters are lying around sunning by the pool ... thinking about things that could possibly go wrong.

Then it becomes a different system you know ... it comes down to having the general riff-raff out of here. 
They are not going to come over the wall and they are not going to come to your door asking if they can have a job. The fear that someone if they are standing around might grab a bicycle off of the lawn or go in the open door and grab the cell phone that has been taken care of. But look ... now they are saying ... and this is the paranoia in a crime environment in this country ... people are saying that the gardener, a free black guy who walks in at 6:00 in the morning and works all day with no problem ... people see him walking to leave for the day and they see a black male and a threat walking. That, to me, is paranoia.

Really ... that is not even considered the biggest problem. There is a huge amount of black females on the estate ... 2.2 domestics per household ... they could stick something in their bag so they get searched randomly on the way out of the estate while going through the security turnstile.

Matthew: And they have to be off of the estate at a certain time correct?

George: Yes ... they have to be off by 6:00 but all of these people who grew up with domestics around all of the time forget that they agreed to not have live-in domestics so they forget all of the time which causes a large amount of work for us as well ... all of this is for the fear of crime. Is it a rational fear? It doesn't really matter, if the residents are willing to fork over the money ... hundreds of thousands of Rand for buses, drivers, petrol, and maintenance to not have people walking around the estate like in the real world who are not really going to do anything then so be it.

Matthew: So it seems like even though crime has been solved on the estate more or less, the people who live here have to find something to be worried about.

George: You still get Mrs so and so calling up telling us that there is a strange man walking around on the estate. They are all nervous ... look, with the crime stats in South Africa every family has got some issue either directly, in a family or through some personal contact ... we don't know what all of the motivations are.

Matthew: But do you think the central motivation for living on the estate is crime?

George: It is security ... they use the word security. If you speak to the estate managers they will tell you that when people are asked during their induction for new residents or owners what the main reason is for moving here they will say security. It is absolutely way out in front. Where 
I come in is when their perception of security needs teeth.

The "teeth" that George refers to are a slew of new technological and other advances that are consistently being integrated into the security protocol of the estate, including the speculative possibility of DNA fingerprinting that he is currently looking into. Thus, the general belief from the security company is that they have done their job. Crime from the outside is no longer a threat to the individuals who live on the estate while they are within the wall and past secured access points. Yet, the paranoia and perception of crime causes residents to invent crime scenarios where none exist within the protected space. While "streets are real" and crime is rampant in the "real" South Africa beyond the wall, the crime within the gated estate is petty at best and usually created by paranoia. The South Africa imagined within the estate is totally free of crime and, after the buses roll around and their passengers exit promptly by 6:00 pm, essentially free of people of color besides the small minority who can afford to live there. Just as the community is imagined, the crime is invented within the estate and generated by a culture of fear. Yet, the culture of fear is depended upon because it fuels development and capital, as George continues:

George: People who spend 2 or 3 million to buy a house in a secured environment want to believe ... when they are buying here they don't question too much because they want to believe that by buying into Springfield Hills that they will be totally secure. The fact is whether they are or not is not evident and they are not asking the right questions ... the sales people are pushing all of the right buttons to get the big sell and it helps us as well ... more money is being pumped in. There is no guarantee but let's face it ... the TVs in this place are too big to carry out.

You could go to any suburb or gated estate in South Africa and say that the world is coming to an end and they will say well what the hell are you worried about ... we lock ourselves in here at night and set alarms and have armed response security guards ... it's when the people leave or their guests leave to go back and forth between these secured spaces where the real fear is.

\section{CONCLUSION}

Setha Low states that, "Gated communities respond to middleclass and upper-middle-class individual's desire for community and intimacy and facilitate avoidance, separation, and surveillance. They bring individual preferences, social forces, and the physical 
environment together in an architectural reality and cultural metaphor" (Low 2003: 391). In contemporary South Africa the gated community is often assumed to be a cultural metaphor for a newly inscribed apartheid reminiscent of a historical past that the "New" South Africa is striving to move beyond. For residents and developers of gated communities attached to a "culture of fear," exacerbated by the media and compounded by perception, these developments are believed to be necessary spaces to avoid the consequences of crime despite its actual or perceived abund-

ance. For many government officials, city planners, and citizens of South Africa the gated community development presents multiple problems in terms of the financial, infrastructure, and civil progress of the country. As forums are sponsored by independent think tanks, and continued academic and public speculation is forwarded about crime in South Africa, the gated community development in the country continues at a rapid pace with no sign of ebbing, particularly in Durban where it has grown exponentially. And, alongside this continued development is a consistent dialogue of crime narratives and an increasing perception that crime is integrally attached to the idea of South African citizenry.

\section{NOTES}

1. This is, of course, dependent on what type of metropolis a suburban space is attached to as the urban/suburban dichotomy is not the same globally as many suburbs of major global cities are not necessarily ideal spaces but are places marginal populations are forced to live, as witnessed during the Paris riots of 2005.

2. Many forms of media in South Africa deal with the topic of crime, including music in the form of Kwaito (Steingo 2005) and several television serials. Informants have anecdotally stated that they believe most people internationally associate South Africa with crime and often refer to the most internationally recognized form of media to come out of the country recently, the film Tsotsi, as an example of this.

3. In March 2005 the South African Human Rights Commission released a report specifically focused on road closures in Johannesburg and throughout the country as a possible human rights violation concerning access and mobility for South African citizens. As the report states, “Many complainants alleged that their human rights were violated by certain security measures used at the boom gates. They alleged that security personnel manning the boom gates insisted that they signed registers and divulged personal information before being granted access to enclosed suburbs. It was also allegedly that in certain cases individuals were being denied access solely on a racial basis" (Kollapen 2005: 7). 
4. Examples of these websites are www.crimeexposouthafrica. co.za and crimexposouthafrica.net, which go in and out of service but can be found through historical research tools on the Web.

5. The name of the community where research was conducted as well as the names of individuals have been substituted with pseudonyms in accordance with confidentiality agreements and ethical concerns in ethnographic research.

6. Carte Blanche is a popular news magazine television show in South Africa.

\section{REFERENCES}

Altbekar, A. 2005. "Is South Africa Really the World's Crime Capital?" South African Crime Quarterly 11: 1-8.

Ballard, R. 2004. "Assimilation, Emigration, Semigration and Integration: 'White' Peoples Strategies for Finding a Comfort Zone in Post-apartheid South Africa." In N. Distiller and M. Steyn (eds) Under Construction: "Race" and Identity in South Africa Today. pp. 51-66. Johannesburg: Heinemann.

Ballard, R. 2005. "Slaughter in the Suburbs: Testing White South Africans' Non-racism." Paper presented at the International Critical Psychology Conference, University of KwaZulu-Natal, Durban, June 2005.

BBC News. "South Africa's Growing Private Army." BBC News March 23, 2004.

Blakely, E. and M. G. Snyder. 1997. Fortress America: Gated Communities in the United States. Washington DC: Brookings Institute Press.

Bremner, L. 2004. "Bounded Spaces: Demographic Anxieties in Post-apartheid Johannesburg." Social Identities 10, 455-68.

Caldeira, T. 1996. "Fortified Enclaves: The New Urban Segregation." Public Culture 8(2): 303-28.

Czegledy, A. 2004. "Getting Around Town: Transportation and the Built Environment in Post-apartheid South Africa." City and Society 16(2): 63-92.

Davis, M. 1992. City of Quartz: Excavating the Future of LoS Angeles. New York: Vintage Books.

Dirsuweit, T. and A. Wafer. 2005. "Fear and Loathing in Johannesburg: Constructing New Urban Identities within Gated Communities." Paper presented at the Territory, Control and Enclosure: The Ecology of Urban Fragmentation Conference, Pretoria, March 2005.

Durington, M. 2006. “Race, Space and Place in Suburban Durban: An Ethnographic Assessment of Gated Community Culture. GeoJournal 66: 147-60.

Freund, B. and V. Padayachee (eds). 2002. (D)urban Vortex: South African City in Transition. Pietermaritzburg: University of Natal Press. 
Glassner, B. 1999. The Culture of Fear. New York: Basic Books.

Jackson, K. 1985. Crabgrass Frontier: The Suburbanization of the United States. New York: Oxford University Press.

Jürgens, U., M. Gnad and J. Bähr. 2003. "New Forms of Class and Racial Segregation: Ghettos or Ethnic Enclaves?" In R. Tomlinson, R. A. Beauregard, L. Bremner and X. Mangu (eds) Emerging Johannesburg: Perspectives on the Post-apartheid City, pp. 56-70. London: Routledge.

Kollapen, J. 2005. Road Closures/Boom Gates: Report of the South African Human Rights Commission. http://www.sahrc.org.za/ sahrc_cms/publish/cat_index_41.shtml\#12 (accessed August 15, 2008).

Kruger, T., K. Landman and S. Liebermann. 2001. Designing Safer Places: A Manual for Crime Prevention through Planning and Design. South African Police Service and the CSIR: Pretoria.

Landman, K. 2002. "Gated Communities in South Africa: Building Bridges or Barriers?" Paper presented at the International Conference on Private Urban Governance, Mainz, March 2002.

Landman, K. and M. Schonteich. 2002. "Urban Fortresses: Gated Communities as a Reaction to Crime." African Security Review 11(4): 71-85.

Leggett, T. 2005. “The State of Crime and Policing." In J. Daniel, R. Southall and J. Lutchman (eds) State of the Nation: South Africa 2004-2005, pp. 144-76. Cape Town: Human Science Research Council Press.

Lemanski, C. 2005. "Spaces of Exclusivity or Connection? Linkages between a Security Village and Its Poorer Neighbour in a Cape Town Master Plan Development." Paper presented at the Territory, Control and Enclosure: The Ecology of Urban Fragmentation Conference, Pretoria, March 2005.

Lemanski, C., Karina Landman and Matthew Durington. 2008. “Divergent and Similar Experiences of 'Gating' in South Africa: Johannesburg, Durban and Cape Town." Urban Forum 19(2): 133-58.

Low, S. 1997. Urban Fear: Building Fortress America. City and Society, Annual Review. Washington DC: American Anthropological Association.

Low, S. 2003a. Behind the Gates: The New American Dream. London: Routledge.

Low. S. -2003b: “The Edge and the Center: Gated Communities and the Discourse of Urban Fear." In S. Low and D. Lawrence-Zuniga (eds) The Anthropology of Space and Place: Locating Culture, pp. 387-407. Blackwell Publishers: Oxford.

Low, S. 2005. “Towards a Theory of Urban Fragmentation: A Crosscultural Analysis of Fear, Privatization and the State." Paper read at the Territory, Control and Enclosure: The Ecology of Urban Fragmentation Conference, Pretoria, March 2005. 
Marcuse, P. 1997. "The Ghetto of Exclusion and the Fortified Enclave. American Behavioural Scientist 41: 311-36.

Mistry, D. 2004. "Falling Crime, Rising Fear: 2003 National Victims of Crime Survey." South African Crime Quarterly 8: 17-24.

Nattrass, N. 2003. "The State of the Economy: A Crisis of Employment." In J. Daniel, A. Habib and R. Southall (eds) State of the Nation: South Africa 2003-2004, pp. 141-7. Cape Town: Human Science Research Council.

National Hi Jack Prevention Academy. 2008. http://www.hijack. co.za/ (accessed September 5, 2008).

Netstar. 2008. http://www.netstar.co.za/ (accessed September 5, 2008).

Newham, G. 2008. "Reclaiming Our Homes? Tackling Residential Robbery in Gauteng." South African Crime Quarterly 23: 1-8.

Pelser, E. 2007. “How We Really Got it Wrong: Understanding the Failure of Crime Prevention." South African Crime Quarterly 22: 1-5.

Robinson, S. 2005. "The Political Economy of Territorial Control in Historical Perspective: Comparing Mediaeval and Modern Walled Communities." Paper presented at the Territory, Control and Enclosure: The Ecology of Urban Fragmentation Conference, Pretoria, March 2005.

Rutheiser, C. 1996. Imagineering Atlanta: The Politics of Place in the City of Dreams. New York: Verso.

Smith, N. 1996. The New Urban Frontier: Gentrification and the Revanchist City. London: Routledge.

Sparks, A. 2003. Beyond the Miracle: Inside the New South Africa. Johannesburg: Jonathan Ball Publishers.

Steingo, G. 2005. "South African Music after Apartheid: Kwaito, the 'Party Politic,' and the Appropriation of Gold as a Sign of Success." Popular Music and Society 28(3): 333-57.

Taleb, Nasseema. 2005. "Muslim Identity and Gated Community Development in Durban." Master's Thesis, University of KwaZuluNatal.

\section{Filmography}

Tsotsi. 2005. Dir. Gavin Hood. The UK Film \& TV Production Company plc. 